\title{
PENERAPAN MODEL PEMBELAJARAN PROJECT CITIZEN UNTUK MENINGKATKAN KETERAMPILAN BERPIKIR KRITIS DAN KREATIF SISWA
}

\author{
Luqman \\ SD Sabilillah Malang, Jalan Ahmad Yani 15 Blimbing Malang \\ Email: luqy_sabilillah@yahoo.co.id
}

\begin{abstract}
The purpose of this study are: (1) to describe the application of the instructional model of project citizen to improve the ability of critical and creative thinking; (2) to know the improvement of critical thinking ability by applying the instructional model of project citizen; and (3) to know the improvement of creative thinking ability by applying the instructional model of project citizen. This study uses a classroom action research design (PTK). The subjects of the study were 5th grade students of SD Negeri Sabilillah Malang. The research data were obtained from: observation of teacher activity; observation of student activities; and analysis of student learning outcomes. The results concluded that the application of the instructional model of project citizen can improve critical thinking skills and creative, which is done through six steps, namely: identify problems; choose a problem; collect information; developing portfolio; presents portfolio; and reflection on the learning experience. Application of the instructional model of project citizen can improve critical thinking skill, that is Cycle I equal to 74.3 to 83.9 in Cycle II. In addition, the application of the instructional model of project citizen can also improve the skills of creative thinking, which is Cycle I of 70.8 to 75.6 in Cycle II.
\end{abstract}

Keywords: the instructional model of project citizen, creative thinking, critical thinking

\begin{abstract}
Abstrak: Tujuan dari penelitian ini adalah: (1) mendeskripsikan penerapan model pembelajaran project citizen untuk meningkatkan kemampuan berpikir kritis dan kreatif; (2) mengetahui peningkatan kemampuan berpikir kritis dengan menerapkan model pembelajaran project citizen; dan (3) mengetahui peningkatan kemampuan berpikir kreatif dengan menerapkan model pembelajaran project citizen. Penelitian ini menggunakan desain penelitian tindakan kelas (PTK). Subjek penelitian adalah siswa Kelas 5 SD Negeri Sabilillah Malang. Data penelitian diperoleh dari: pengamatan kegiatan guru; pengamatan kegiatan siswa; dan analisis hasil belajar siswa. Hasil penelitian menyimpulkan bahwa penerapan model pembelajaran project citizen dapat meningkatkan keterampilan berpikir kritis dan kreatif, yang dilakukan melalui enam langkah, yaitu: mengidentifikasi masalah; memilih masalah; mengumpulkan informasi; mengembangkan portofolio; menyajikan portofolio; dan refleksi pada pengalaman belajar. Penerapan model pembelajaran project citizen dapat meningkatkan keterampilan berpikir kritis, yaitu Siklus I sebesar 74,3 menjadi 83,9 pada Siklus II. Selain itu, penerapan model pembelajaran project citizen juga dapat meningkatkan keterampilan berpikir kreatif, yaitu Siklus I sebesar 70,8 menjadi 75,6 pada Siklus II.
\end{abstract}

Kata kunci: model pembelajaran project citizen, berpikir kreatif, berpikir kritis

Peluang pengembangan keterampilan berpikir dan bersikap untuk menjadikan warga negara yang baik dalam mata pelajaran PKn ternyata kurang direspons secara maksimal oleh guru. Keterampilan berpikir di tingkat pendidikan dasar belum tertangani secara sistematis dan masih dilaksanakan secara parsial (Rofi'uddin, 2000).
Sebagai akibatnya, kemampuan berpikir lulusan pendidikan dasar sangat rendah. Rendahnya kemampuan berpikir kritis dan kreatif lulusan pendidikan dasar perlu menjadi bahan kajian sendiri (Rofi'uddin, 2000). Jika dasar berpikir tidak dikuasai dengan baik, maka dampaknya dirasakan sampai jenjang pendidikan selanjutnya. Beberapa 
indikasi pembelajaran yang kurang mengarah kepada tujuan terlihat dari beberapa penelitian. Akbar (2002) menyebutkan pembelajaran kurang menyenangkan yang berakibat pada kurang tertariknya siswa pada mata pelajaran bahkan meremehkannya. Hal tersebut disebabkan materi yang belum utuh, tidak progresif, dan belum tertata dengan baik. Pendidikan PKn SD terjebak dan telah terpeleset pada ranah kognitif, yang seharusnya memperhatikan keseimbangan ranah kognitif, afektif, psikomotor, dan konatif (Akbar, 2009).

Masih belum berkembangnya keterampilan berpikir kritis dan kreatif siswa SD Islam Sabilillah Malang pada saat menjawab pertanyaan pada LKS, tentunya tidak terlepas dari proses pembelajaran yang didesain oleh guru. Proses pembelajaran belum dirancang untuk melatih siswa mengidentifikasi masalah, merumuskan masalah, merumuskan solusi maupun mencari alasan yang mendukung serta menarik kesimpulan. Selain itu, siswa juga belum dilatih dan dibiasakan mengemukakan gagasan-gagasan baru dalam menyelesaikan masalah. Salah satu instructional treatment dalam pembelajaran PKn untuk mencapai tujuan-tujuan di atas adalah Project Citizen. Model pembelajaran ini merupakan perlakuan pembelajaran yang pertama kali digunakan pada tahun 1992 di California. Kemudian program ini dikembangkan oleh Center for Civic Education (CCE) pada tahun 1995 (Budimansyah, 2009). Model ini telah diadaptasi menjadi model Praktik Belajar Kewarganegaraan yang diujicobakan oleh Center for Indonesian Civic Education (CICED) bekerja sama dengan Center for Civic Education (CCE) dan Kanwil Depdiknas Jawa Barat.

Hodijah (2010) berdasarkan penelitiannya menyimpulkan terdapat pengaruh model pembelajaran Project Citizen terhadap pengembangan kompetensi kewarganegaraan. Jayadiputra (2010) menyimpulkan model Project Citizen dengan enam langkah pembelajarannya terbukti berpengaruh secara siginifikan terhadap keterampilan berpikir kritis siswa, yaitu sebesar 0,845 atau sebesar 84,5\%. Project Citizen dikembangkan dari model pendekatan kritis atau reflektif yang dirintis oleh John Dewey dengan paradigma how we think. Project Citizen adalah pembelajaran yang berbasis masalah untuk mengembangkan pengetahuan, kecakapan, dan watak warga negara demokratis yang memungkinkan dan mendorong keikutsertaan dalam pemerintahan dan masyarakat sipil (Budimansyah, 2009). Pendekatan pembelajaran Project Citizen berorientasi pada proses berpikir kritis, kreatif, dan pemecahan masalah (Budimansyah, 2009). Model pembelajaran Project Citizen juga dikenal dengan portofolio based civic education project, yang dirancang dalam disain pembelajaran dimana memadukan secara sinergis model-model pemecahan masalah, penelitian sosial, perlibatan sosial, belajar kelompok, simulasi, dialog mendalam dan berpikir kritis serta kreatif, klarifikasi nilai, dan pembelajaran demokratis.

Fokus perhatian dari langkah-langkah model Project Citizen adalah pengembangan pengetahuan kewarganegaraan, keterampilan kewarganegaraan, kepercayaan diri warga negara, komitmen warga negara, dan kompetensi warga negara yang bermuara kepada kemampuan mengambil keputusan yang kritis, kreatif, bernalar, serta bertanggung jawab (Budimansyah, 2009). Atau dengan kata lain, fokus model pembelajaran Project Citizen adalah melatih siswa untuk berpikir kritis dan kreatif dalam pemecahan masalah. Kritis dan kreatif merupakan bagian dari proses berpikir. Berpikir merupakan kegiatan manipulasi data, fakta, dan informasi untuk membuat keputusan perilaku. Presseisen mengemukakan bahwa berpikir adalah suatu aktivitas mental yang bertujuan untuk memperoleh pengetahuan (Jayadiputra, 2010). Siswa dalam proses pembelajaran tidak hanya berpikir mengenai pengetahuan yang diterima saja, tetapi perlu juga dilatih supaya memiliki keterampilan berpikir sebagai sarana yang dapat mengantarkan siswa untuk membuat keputusan perilaku yang sesuai dengan tujuan.

Keterampilan berpikir kritis dalam kehidupan sangat diperlukan karena manusia akan selalu dihadapkan kepada permasalahan yang memerlukan pemecahan. Keterampilan berpikir kritis merupakan modal dasar atau modal intelektual yang sangat penting bagi setiap orang dan merupakan bagian fundamental dari kematangan manusia (Baisa, 2010). Berpikir kritis ialah sebuah proses yang bertujuan membuat keputusan masuk akal mengenai apa yang dipercayai dan apa 
yang dikerjakan oleh seseorang. Berpikir kritis merupakan salah satu tahapan berpikir tingkat tinggi. Beberapa kemampuan berpikir kritis ialah: kemampuan mendefinisikan masalah; kemampuan menyeleksi informasi untuk pemecahan masalah; kemampuan untuk mengenali asumsi-asumsi; kemampuan merumuskan hipotesis; dan kemampuan menarik simpulan (Amri, 2010).

\section{METODE}

Pendekatan yang digunakan dalam penelitian ini adalah Penelitian Tindakan Kelas (PTK). Penelitian ini menggunakan model PTK "guru sebagai peneliti" dengan mengacu kepada model siklus PTK yang dikembangkan oleh Kemmis dan Taggart (1990), yaitu: (1) perencanaan; (2) tindakan dan observasi; dan (3) refleksi, serta perencanaan ulang berdasarkan hasil refleksi untuk siklus berikutnya. Penelitian penerapan model pembelajaran Project Citizen untuk meningkatkan keterampilan berpikir kritis dan kreatif pada mata pelajaran PKn dilakukan di Kelas V-D SD Islam Sabilillah Malang yang terletak di Jalan A. Yani 15 Malang.

Data yang dikumpulkan selama penelitian tindakan meliputi: (1) data tentang kegiatan guru dalam proses pembelajaran dengan model pembelajaran Project Citizen untuk meningkatkan keterampilan berpikir kritis dan kreatif; (2) data tentang kegiatan siswa dalam proses pembelajaran dengan model pembelajaran Project Citizen untuk meningkatkan keterampilan berpikir kritis dan kreatif; (3) data hasil belajar siswa tentang keterampilan berpikir kritis; dan (4) data hasil belajar siswa tentang keterampilan berpikir kreatif. Penelitian tindakan penerapan model pembelajaran Project Citizen untuk meningkatkan keterampilan berpikir kritis dan kreatif ini menggunakan 3 instrumen, yaitu lembar observasi, tes keterampilan berpikir kritis, dan tes keterampilan berpikir kreatif.

Data yang diperoleh dari lembar observasi kegiatan guru, lembar observasi kegiatan siswa, tes keterampilan berpikir kritis, serta tes keterampilan berpikir kreatif dikumpulkan dan dianalisis secara deskriptif. Data-data kualitatif maupun kuantitatif tersebut kemudian dibandingkan antara data pada siklus ke-1 dan siklus selanjutnya. Indikator keberhasilan penerapan model pembelajaran Project Citizen untuk meningkatkan keterampilan berpikir kritis dan kreatif pada siswa Kelas V-D SD Islam Sabilillah Malang, adalah: (1) terdapat peningkatan prosentase keterlaksanaan langkahlangkah model pembelajaran Project Citizen; (2) terdapat peningkatan rata-rata nilai butir soal yang mencerminkan keterampilan berpikir kritis; (3) terdapat peningkatan rata-rata nilai butir soal yang mencerminkan keterampilan berpikir kreatif; dan (4) jumlah siswa yang mencapai Kriteria Ketuntasan Minimal $(\mathrm{KKM}) \geq 80 \%$.

\section{HASIL}

Penerapan model pembelajaran Project Citizen untuk meningkatkan keterampilan berpikir kritis dan kreatif dilaksanakan melalui dua siklus.

\section{Siklus I}

Penerapan model pembelajaran Project Citizen untuk meningkatkan keterampilan berpikir kritis dan kreatif pada siswa Kelas V-D SD Islam Sabilillah Malang pada Siklus I meliputi tiga tahap, yaitu perencanaan, tindakan dan observasi serta refleksi. Siklus I dilaksanakan selama delapan kali pertemuan dengan alokasi waktu setiap pertemuan 2 jam pelajaran ( 2 x 30 menit).

\section{Perencanaan}

Kegiatan perencanaan tindakan pada siklus I didasarkan kepada hasil temuan pengamatan pendahuluan. Kegiatan yang dilakukan pada tahap ini adalah: (1) merancang skenario pembelajaran yang dituangkan dalam RPP pertemuan pertama; (2) menyusun Lembar Kerja Siswa (LKS); (3) menyusun lembar observasi aktifitas guru; (4) menyusun lembar observasi aktifitas siswa; (5) menyiapkan satu orang guru sebagai observer dan satu petugas untuk mendokumentasikan proses tindakan; (6) menyusun lembar observasi aktifitas penerapan nilai-nilai luhur Pancasila ketika proses pembelajaran; dan (6) menyusun instrumen tes.

\section{Tindakan dan Observasi}

Tindakan penelitian tentang penerapan langkah-langkah model pembelajaran Project Citizen untuk meningkatkan keterampilan berpikir kritis dan kreatif pada siklus pertama meliputi 6 (enam) langkah. Langkah-langkah tersebut adalah: 


\section{Mengidentifikasi Masalah}

Kegiatan mengidentifikasi masalah dilakukan selama tiga kali pertemuan. Pembelajaran diarahkan untuk membangkitkan motivasi, memberi pemahaman awal tentang materi keputusan bersama, dan penyampaian tujuan pembelajaran. Kegiatan apersepsi dilakukan melalui kegiatan tanya jawab untuk mengetahui pemahaman siswa mengenai hal-hal yang harus diputuskan bersama di lingkungan kelas dan rumah. Selanjutnya untuk membantu siswa memahami sikap-sikap yang sebaiknya dilakukan ketika musyawarah, siswa melihat tiga tayangan video musyawarah yang menerapkan nilai-nilai Pancasila dan yang tidak menerapkan nilai-nilai Pancasila. Kegiatan pendahuluan diakhiri dengan penyampaian tujuan pembelajaran yaitu mempraktikkan musyawarah untuk menyelesaikan masalah yang terdapat di kelas. Selain penyampaian tujuan, siswa juga diberi motivasi bahwa pada pelajaran PKn kali ini, Kelas V-D akan mengkaji masalah di kelas serta berusaha mencari cara menyelesaikan masalah tersebut.

Kegiatan inti diawali dengan pembentukan kelompok. Masing-masing kelompok terdiri dari 4 sampai 5 siswa. Siswa diberi kebebasan dalam membentuk kelompok. Setelah kelompok terbentuk, siswa diberi penjelasan tentang cara mengidentifikasi masalah. Pada kegiatan ini, untuk membantu pemahaman siswa tentang konsep masalah, guru menampilkan dua puluh empat foto. Foto-foto yang ditampilkan antara lain menggambarkan tentang kebersihan sekolah, kedisiplinan siswa, kebersihan kelas, adab makan siswa, dan sarana sekolah yang kurang terawat. Setelah siswa memahami contoh-contoh masalah, siswa diminta untuk menyebutkan masalah-masalah di Kelas V-D selain yang sudah ditampilkan dalam foto. Pada saat guru melakukan tanya jawab tentang contoh masalah di kelas, terlihat beberapa siswa berbicara tanpa mengangkat tangan terlebih dahulu. Selain itu, terlihat juga siswa yang berbicara dengan teman ketika ada teman yang sedang berpendapat. Untuk menanamkan nilai-nilai yang dilakukan pada saat orang lain menyampaikan pendapat, guru selalu mengingatkan kepada siswa untuk diam dan tidak menyalahkan pendapat orang lain.
Hasil pengamatan terhadap aktivitas kelompok dalam menerapkan keterampilan berpikir kritis selama proses identifikasi kelompok adalah semua kelompok (100\%) sudah mampu menemukan 3 (tiga) masalah yang terdapat di Kelas V-D. Sedangkan dalam penyampaian alasan, belum ada kelompok yang mampu menyampaikan lebih dari tiga alasan dengan logis. Hanya dua kelompok $(28,6 \%)$ yang sudah menyampaikan tiga alasan yang logis, yaitu kelompok I dan III. Sedangkan sisanya, yaitu lima kelompok $(71,4 \%)$ hanya mampu menyampaikan dua alasan yang logis. Pada saat proses musyawarah, guru selalu memotivasi dan mengingatkan siswa untuk menerapkan nilai-nilai luhur Pancasila. Namun pada saat musyawarah, masih banyak siswa yang berbicara sendiri ketika ada temannya yang berpendapat. Hasil observasi tercatat 5 siswa $(15,6 \%)$ sudah dapat menghormati pendapat teman, tidak memaksakan pendapat dan diam ketika teman sedang berpendapat. Tercatat 14 siswa $(43,8 \%)$ masih sering berbicara dengan temannya jika ada teman yang berbicara dan terdapat 13 siswa (40,6\%) yang masih memaksakan pendapat dan sering berbicara dengan teman ketika temannya berpendapat.

Kegiatan pembelajaran masih melanjutkan proses identifikasi masalah. Hal ini disebabkan karena hasil Lembar Kerja 1 masih jauh mencerminkan keterampilan berpikir kritis. Ketujuh kelompok sudah memberikan dan menuliskan alasan pada lembar kerja kelompok. Dari aspek jumlah, masing-masing kelompok sudah menuliskan 3 atau lebih alasan. Namun, alasannya yang ditulis belum paham dengan pokok permasalahan. Oleh karena itu, kegiatan pada pertemuan ketiga adalah mengevaluasi dan memperbaiki hasil kerja kelompok dalam mengidentifikasi masalah. Kegiatan evaluasi kerja kelompok ketika proses identifikasi masalah dilakukan dengan cara guru menampilkan alasan masing-masing kelompok di layar LCD. Proses evaluasi hasil kerja di awali dengan penjelasan ulang tentang bagaimana cara membuat alasan dalam memilih suatu masalah.

Berdasarkan hasil pengamatan guru, seperti pada pertemuan sebelumnya, semua kelompok (100\%) sudah menuliskan tiga masalah kelas; empat kelompok $(57,1 \%)$ sudah menuliskan lebih dari tiga alasan yang mencerminkan 
keterampilan berpikir kritis; sedangkan kelompok yang masih mampu menyampaikan tiga alasan dengan logis adalah tiga kelompok (42,9\%). Hasil pengamatan pada pertemuan ketiga, penerapan nilai-nilai luhur Pancasila ketika siswa melakukan musyawarah identifikasi masalah khususnya pada proses menuliskan alasan adalah 6 siswa $(18,8 \%)$ sudah menghormati pendapat teman, tidak memaksakan pendapat dan diam ketika teman sedang berpendapat. Sedangkan siswa yang tidak mendengarkan ketika ada temannya yang berpendapat tercatat 22 siswa $(68,8 \%)$, dan masih ada 4 siswa $(12,5 \%)$ yang belum bisa diam ketika orang lain berpendapat dan memaksakan pendapatnya untuk diterima.

\section{Memilih Masalah}

Langkah kedua pada model pembelajaran Project Citizen adalah memilih masalah. Kegiatan pembelajaran dilaksanakan pada pertemuan keempat. Pada proses memilih masalah, siswa kembali dibimbing dan dipandu untuk menggunakan keterampilan berpikir kritis. Secara operasional, langkah-langkah pembelajaran diuraikan sebagai berikut. Di awali dengan kegiatan pendahuluan. Guru memberi penguatan dan motivasi tentang hasil kerja siswa pada pertemuan sebelumnya. Selanjutnya guru menyampaikan tujuan pembelajaran, yaitu Kelas V-D akan menentukan satu masalah untuk dikaji, dibahas, dan mencari jalan keluar dari masalah tersebut. Proses penentuan masalah akan dilakukan melalui cara musyawarah kelas. Kegiatan selanjutnya adalah kegiatan inti. Masing-masing kelompok mempresentasikan 3 (tiga) masalah di Kelas V-D yang telah diidentifikasi sekaligus membacakan satu masalah yang telah dipilih dan disepakati beserta alasannya. Proses selanjutnya adalah kelas dipandu untuk memilih satu dari tujuh masalah yang telah dipresentasikan.

Namun sebelumnya siswa diberi penjelasan tentang cara-cara dalam mengambil keputusan, yaitu musyawarah mufakat dan pengambilan suara terbanyak (voting). Kemudian siswa diberi penjelasan tentang kelebihan dan kelemahan masing-masing cara mengambil keputusan. Siswa dipandu untuk mengambil keputusan dengan cara musyawarah mufakat sebagai ciri khas bangsa Indonesia. Hasil pengamatan aktivitas pengambilan kesimpulan sebagai bagian dari keterampilan berpikir kritis adalah tiga kelompok (42,9\%) sudah mampu mengambil kesimpulan dengan disertai alasan yang cukup logis yaitu Kelompok I, II, dan IV. Sedangkan empat kelompok yang lain $(57,1 \%)$ yaitu Kelompok III, V, VI, dan VII, dalam proses pengambilan kesimpulan masih belum disertai alasan yang cukup logis. Pada saat proses penentuan masalah kelas, sudah tidak terdapat lagi siswa yang memaksakan pendapat. Hal tersebut terjadi karena guru memberi motivasi agar siswa lapang dada atau tidak marah ketika pendapatnya tidak diterima. Namun masih terdapat 27 siswa $(84,4 \%)$ yang belum bisa diam ketika ada teman yang berbicara. Sisanya, 5 siswa $(15,5 \%)$ sudah mampu menghormati pendapat orang lain dan diam ketika orang lain sedang berbicara.

\section{Mengumpulkan Informasi}

Langkah ketiga model pembelajaran Project Citizen adalah membentuk kelompok riset untuk mengumpulkan informasi yang nantinya akan dituangkan dalam portofolio. Pada langkah ini siswa difasilitasi, dibimbing, dipandu, dan dimotivasi untuk mengumpulkan informasi maupun faktafakta sebanyak mungkin tentang masalah siswa yang tidak sopan kepada guru. Informasi maupun fakta-fakta nantinya akan digunakan untuk merumuskan pokok permasalahan dan mencari solusi atau penyelesaian masalah tersebut. Proses pembelajaran ini diarahkan untuk mengembangkan keterampilan berpikir kritis dan kreatif. Siswa dipandu dan dibimbing untuk bertanya kepada narasumber, mengungkapkan pendapat, maupun menyampaikan alasan. Selain itu, siswa juga dibimbing untuk kreatif menyampaikan pertanyaan-pertanyaan kepada narasumber.

Kelompok riset A difasilitasi untuk mencari informasi melalui wawancara kepada guru-guru bidang studi. Kelompok riset B difasilitasi untuk bertemu dengan guru yang menurut siswa $\mathrm{V}$ D pernah diperlakukan tidak sopan. Selain itu, kelompok juga difasilitasi wawancara dengan wali Kelas V-D untuk menggali hal-hal apa yang telah dilakukan wali kelas untuk menyelesaikan masalah. Kelompok B ternyata juga menuliskan fakta-fakta tentang siswa yang pernah bersikap tidak sopan kepada guru. Sedangkan kelompok riset $\mathrm{C}$ difasilitasi untuk mengembangkan gagasan- 
gagasan baru guna menyelesaikan masalah. Kelompok $\mathrm{C}$ diarahkan untuk bergabung dengan kelompok $\mathrm{B}$ dalam melakukan pengumpulan informasi. Hal ini dilakukan agar kelompok C dalam membuat solusi atau penyelesaian masalah didasarkan pada data-data yang lengkap.

\section{Mengembangkan Portofolio}

Kegiatan mengembangkan portofolio dilaksanakan pada pertemuan keenam. Langkahlangkah pembelajaran diuraikan sebagai berikut. Di awali dengan siswa berkumpul bersama kelompok riset. Kemudian masing-masing kelompok riset menyampaikan informasi-informasi yang didapatkan pada pertemuan sebelumnya. Sebab, informasi-informasi tersebut akan ditulis dalam portofolio. Oleh karena itu, guru perlu mengetahui informasi-informasi yang didapatkan oleh masingmasing kelompok riset. Selain itu, kegiatan presentasi ini dilakukan untuk mengetahui gagasangagasan kelas guna menyelesaikan masalah siswa yang tidak sopan kepada guru. Guru dalam hal ini berperan untuk memfasilitasi siswa lain untuk berpikir kreatif menyampaikan gagasan-gagasan terkait bagaimana cara menyelesaikan masalah kelas. Hasil pengamatan aktivitas kelompok dalam menerapkan keterampilan berpikir kritis dan kreatif ketika proses mengembangkan portofolio adalah kelompok riset A, yaitu kelompok III, V, dan VII sudah menyajikan masalah pada portofolio dengan disertai lebih dari tiga alasan yang logis.

Kelompok riset $\mathrm{B}$ yang bertugas mengumpulkan informasi yang berkaitan dengan anak yang tidak sopan kepada guru sudah melakukan wawancara dengan beberapa guru dan siswa. Hasil wawancara sudah dituangkan oleh kelompok riset B pada portofolio. Sedangkan kelompok riset $\mathrm{C}$ sudah menyusun lebih dari 3 gagasan untuk menyelesaikan masalah masalah anak Kelas V-D yang tidak sopan kepada guru sebagai wujud aspek keterampilan berpikir kreatif. Aspek keterampilan berpikir kreatif juga terlihat pada penyajian portofolio kelompok yang sangat menarik. Portofolio masing-masing kelompok penuh dengan kreasi hiasan maupun tulisan. Pada akhir pembelajaran, proses pengembangan portofolio kelas masih belum selesai. Kegiatan penutup pembelajaran diisi dengan memberikan motivasi tentang hasil portofolio kelompok.

\section{Menyajikan Portofolio}

Langkah kelima model pembelajaran Project Citizen adalah menyajikan portofolio. Kegiatan ini dilakukan pada pertemuan ketujuh. Kegiatan penyajian portofolio dilakukan untuk melatih siswa mempresentasikan serta bertanggung jawab atas gagasan yang telah disusun. Pada pertemuan ketujuh, masing-masing kelompok riset diminta untuk menunjuk salah seorang wakil untuk mempresentasikan portofolio dihadapan wali kelas (Bu Ttk) dan wakil kepala sekolah bidang kesiswaan (Pak Isn). Setiap kelompok diberi waktu 10 menit untuk presentasi.

Selain itu, Pak Isn maupun Bu Ttk diberi kesempatan untuk bertanya kepada masingmasing kelompok. Hasil pengamatan guru ketika penyajian portofolio adalah siswa terlihat kurang menguasai isi portofolio. Hal tersebut ditandai dengan seringnya siswa menjelaskan sambil membaca portofolio. Sehingga ketika proses penyajian portofolio terlihat siswa kurang memahami permasalahan. Hal ini membuat guru harus sering mengingatkan siswa untuk tidak membaca portofolio ketika presentasi.

\section{Refleksi Pengalaman Belajar}

Langkah terakhir model pembelajaran Project Citizen adalah refleksi pengalaman belajar. Kegiatan refleksi dilakukan pada pertemuan. Kegiatan ini dilaksanakan pada akhir pembelajaran setelah siswa menyajikan portofolio. Pada kegiatan ini, siswa diminta untuk menyampaikan pendapat, apa yang bisa dilakukan Kelas V-D untuk melaksanakan gagasan yang telah diajukan? Setelah itu, guru bertanya kepada siswa: Apa yang sudah Ananda pelajari mulai dari awal mengidentifikasi masalah hingga sekarang?

Banyak jawaban yang muncul dari siswa. Antara lain, belajar memilih masalah, mengatasi masalah, belajar membuat karya dan belajar presentasi. Guru memberikan penguatan bahwa: Di sekitar kita, banyak sekali masalah. Kita jangan diam saja ketika melihat atau menemui masalah. Pada akhir pertemuan, siswa diberi pertanyaan tentang sikap-sikap yang harus dilakukan ketika bermusyawarah. Guru memberi penekanan untuk diam ketika orang lain sedang berpendapat dan 
tidak marah jika pendapat tidak diterima sebagai wujud menghormati pendapat orang lain.

\section{Uji Kompetensi}

Uji Kompetensi (UK) atau Ulangan Harian (UH) dilakukan pada pertemuan kedelapan. Ratarata nilai UK adalah 73,3. Dengan rincian, rata-rata nilai butir soal yang mencerminkan keterampilan berpikir kritis adalah 74,3. Sedangkan rata-rata nilai butir soal yang mencerminkan keterampilan berpikir kreatif adalah 70,3. Berdasarkan hasil tersebut, rata-rata UH masih belum mencapai KKM. Sedangkan siswa yang sudah mencapai KKM yaitu 15 siswa (46,9\%). Berdasarkan hasil temuan-temuan tindakan pada Siklus I, maka hasil tersebut digunakan untuk memperbaiki tindakan pada Siklus II.

Rancangan tindakan pada Siklus II adalah: (1) menyusun perangkat pembelajaran yang menerapkan model pembelajaran Project Citizen; (2) langkah-langkah pembelajaran yang disusun harus dilaksanakan secara efektif dan efisien; (3) untuk efisiensi waktu, pembimbingan siswa guna meningkatkan keterampilan berpikir kritis dan kreatif dilakukan di luar jam pembelajaran; (4) perubahan objek masalah yang dikaji, yaitu masalah di kelas diganti dengan masalah di lingkungan SD Islam Sabilillah Malang; dan (5) untuk mengaktifkan seluruh siswa, ada perubahan kelompok riset. Kelas dibagi menjadi 6 kelompok riset, masing-masing kelompok melakukan enam langkah model pembelajaran Project Citizen, mulai dari mengidentifikasi masalah hingga menyajikan portofolio, harapannya masing-masing siswa dapat lebih maksimal untuk meningkatkan keterampilan berpikir kritis dan kreatif; dan (6) perlu ada hadiah atas hasil kerja kelompok.

\section{Siklus II}

Penerapan model pembelajaran Project Citizen untuk meningkatkan keterampilan berpikir kritis dan kreatif pada siswa Kelas V-D SD Islam Sabilillah Malang pada Siklus II meliputi tiga tahap, yaitu perencanaan, tindakan dan observasi serta refleksi. Siklus II dilaksanakan selama enam kali pertemuan dengan alokasi waktu setiap pertemuan 2 jam pelajaran $(2 \times 30$ menit $)$.

\section{Perencanaan}

Kegiatan perencanaan tindakan pada siklus II didasarkan pada hasil refleksi siklus I. Kegiatan yang dilakukan pada tahap ini adalah: (1) merancang skenario pembelajaran (RPP) yang menerapkan model pembelajaran Project Citizen dengan fokus kajian masalah di lingkungan SD Islam Sabilillah Malang, RPP yang disusun pada siklus II menerapkan prinsip efektifitas kegiatan dan efisiensi alokasi waktu; (2) menyusun LKS yang disesuaikan dengan fokus permasalahan; (3) menyusun lembar observasi aktifitas guru; (3) menyusun lembar observasi aktifitas siswa; (4) menyusun lembar observasi aktifitas penerapan nilai-nilai luhur Pancasila ketika proses pembelajaran; (5) menyusun instrumen tes; dan (6) mempersiapkan hadiah bagi kelompok.

\section{Tindakan dan Observasi}

Tindakan penelitian yang menerapkan langkah-langkah model pembelajaran Project Citizen untuk meningkatkan keterampilan berpikir kritis dan kreatif pada siklus kedua meliputi enam langkah, yakni:

\section{Mengidentifikasi Masalah dan Memilih Masalah}

Pada pertemuan pertama ini, sebelum siswa melakukan identifikasi masalah, guru menayangkan kembali foto-foto yang menggambarkan masalah di sekolah. Ketika siswa melihat foto-foto tersebut, siswa diberi pertanyaan, yaitu: mengapa membuang sampah sembarangan adalah masalah? mengapa anak yang terlambat adalah masalah? dan sebagainya. Proses identifikasi masalah pada Siklus II dilaksanakan dengan cara masing-masing kelompok melakukan identifikasi masalah yang terdapat di lingkungan SD Islam Sabilillah Malang. Setelah itu, masing-masing kelompok menentukan satu masalah untuk dikaji. Objek masalah yang dipilih pada Siklus II berbeda dengan Siklus I. Jika pada Siklus I, masalah yang menjadi objek bahasan adalah masalah di Kelas V-D. Sedangkan pada Siklus II, objek bahasan adalah masalah yang terdapat di lingkungan SD Islam Sabilillah Malang. 
Pada pertemuan pertama, kegiatan identifikasi dan memilih masalah digabung untuk efisiensi waktu namun tidak meninggalkan tujuan penelitian. Penggabungan langkah pertama dan kedua pada model pembelajaran Project Citizen dilakukan karena pada siklus I siswa sudah memahami tentang konsep masalah serta sudah terlatih memberikan dan menyusun alasan/argumentasi terkait masalah yang dipilih. Fokus perhatian guru pada proses ini adalah pembimbingan yang lebih intensif kepada masing-masing siswa dalam kelompok. Kegiatan inti diawali dengan pembentukan kelompok. Guru meminta kepada siswa untuk membentuk menjadi enam kelompok dengan aturan harus ada siswa putra dan putri. Ketika kelompok melaksanakan proses identifikasi dan pemilihan masalah, guru membimbing secara intensif serta memotivasi siswa untuk menggunakan keterampilan berpikir kritis dalam mengidentifikasi dan menentukan masalah. Kelompok dibimbing untuk memutuskan satu masalah berdasarkan alasan yang disampaikan.

Hasil pengamatan terhadap aktivitas siswa ketika proses mengidentifikasi masalah adalah: semua kelompok (100\%) sudah menuliskan tiga masalah kelas; lima kelompok (83,3\%) sudah menuliskan lebih dari tiga alasan yang mencerminkan keterampilan berpikir kritis; sedangkan sisanya yaitu satu kelompok $(16,7 \%)$ yang menyampaikan tiga alasan dengan logis. Hasil pengamatan terhadap siswa ketika proses mengambil kesimpulan untuk menentukan masalah yang akan dikaji kelompok sebagai implementasi keterampilan berpikir kritis diketahui bahwa semua kelompok (100\%) sudah mampu mengambil kesimpulan berdasarkan alasan-alasan yang disampaikan. Hasil pengamatan pada proses identifikasi masalah, penerapan nilai-nilai luhur Pancasila ketika siswa melakukan musyawarah identifikasi masalah adalah 21 siswa (65,6\%) sudah menghormati pendapat teman, tidak memaksakan pendapat dan diam ketika teman sedang berpendapat.

Namun, ketika proses pengambilan keputusan, masih tercatat sebelas siswa $(34,4 \%)$ yang masih tidak mendengarkan ketika ada temannya yang berpendapat. Melalui motivasi dan nasihat yang terus menerus, terdapat peningkatan penerapan nilai-nilai Pancasila pada langkah identifikasi masalah. Peningkatan penerapan nilainilai Pancasila juga terlihat pada proses kelompok melakukan musyawarah memilih masalah. Terdapat 28 siswa $(87,5 \%)$ sudah menghormati pendapat teman, tidak memaksakan pendapat dan diam ketika teman sedang berpendapat. Namun, ketika proses pengambilan keputusan, masih tercatat empat siswa $(1,3 \%)$ yang masih tidak mendengarkan ketika ada temannya yang berpendapat.

\section{Mengumpulkan Informasi}

Kegiatan mengumpulkan informasi dilaksanakan pada pertemuan kedua. Pada langkah ini, siswa difasilitasi dan dibimbing untuk mencari informasi sebanyak mungkin dari berbagai sumber. Kegiatan inti diawali dengan guru mempersilahkan kepada masing-masing kelompok untuk mengumpulkan informasi sebanyak-banyaknya dari berbagai sumber yang ada di sekolah. sebelumnya, guru berpesan agar siswa menggunakan bahasa yang santun dan sopan ketika melakukan wawancara dengan narasumber. Kelompok I terlihat menuju lantai III untuk mengambil gambar tulisan-tulisan yang kurang baik.

Kelompok II yang memilih masalah banyak siswa yang tidak menyiram kamar mandi setelah BAK melakukan pengumpulan data dengan cara menunggu di sekitar kamar mandi. Kelompok III, terlihat menuju ruang Bimbingan dan Konseling (BK). Mereka melakukan wawancara dengan $\mathrm{Bu} \mathrm{Nt}$ terkait akibat-akibat dari terlalu banyak bermain game. Kelompok IV terlihat menuju koperasi sekolah di lantai I. Kelompok melakukan wawancara tentang masalah keterbatasan jajanan yang dijual di koperasi sekolah. Kelompok $\mathrm{V}$ terlihat menuju lantai III untuk menemui koordinator kantin jujur. Sedangkan kelompok VI menuju laboratorium bahasa dengan membawa kamera. Mereka ingin mengambil gambar kondisi laboratorium bahasa yang tidak terawat.

\section{Mengembangkan Portofolio}

Kegiatan mengembangkan portofolio dilaksanakan pada pertemuan ketiga dan keempat. Siswa-siswa terlihat sangat serius menyelesaikan 
portofolio karena guru memberikan target bahwa portofolio harus selesai pada hari itu juga. Guru tetap melakukan pembimbingan kepada kelompok. Pembimbingan guru yang berhubungan dengan keterampilan berpikir kritis dilakukan kepada kelompok dengan cara memberikan pertanyaanpertanyaan terkait alasan yang ditulis oleh kelompok. Harapannya, kelompok menambahkan alasan-alasan lain untuk memperkuat alasan yang sudah dituliskan. Solusi atau cara penyelesaian yang diajukan kelompok juga tidak luput dari perhatian guru. Guru menyampaikan beberapa alternatif jalan keluar kepada kelompok untuk merangsang kelompok agar berpikir kreatif. Hasil pengamatan keterampilan berpikir kritis pada saat proses pengembangan portofolio meliputi aspek penyampaian masalah yang dituangkan dalam portofolio diketahui bahwa Kelompok I, II, III, dan VI $(66,7 \%)$ sudah menuliskan masalah yang menjadi pembahasan kelompok dengan disertai lebih dari tiga alasan yang logis. Sedangkan Kelompok IV dan V (33,3\%) sudah menuliskan rumusan masalah dengan disertai alasan. Namun alasan yang dituliskan masih ada yang belum sesuai dengan rumusan masalah.

Perlakuan guru ketika proses pengembangan portofolio membawa peningkatan keterampilan berpikir kritis siswa. Keterampilan berpikir kreatif yang diimplementasikan dalam kegiatan memberikan gagasan-gagasan baru untuk menyelesaikan masalah tercatat dalam pengamatan, yaitu 5 (lima) kelompok $(83,3 \%)$ sudah mengusulkan lebih dari tiga gagasan. Gagasan-gagasan yang disampaikan kelompok sudah mencerminkan berpikir kreatif karena gagasan-gagasan yang diusulkan belum pernah dilakukan oleh sekolah. Selain itu, implementasi keterampilan berpikir kreatif tampak pada hasil portofolio kelompok. Portofolio yang dihasilkan oleh kelompok penuh dengan hiasan sehingga tampak indah dan menarik. Dalam proses penyelesaian portofolio, lima kelompok $(83,3 \%)$ sudah menyelesaikan portofolio dan hasilnya mencerminkan keterampilan berpikir kreatif.

\section{Menyajikan Portofolio}

Kegiatan ini dilakukan pada pertemuankelima. Kegiatan penyajian portofolio dilakukan untuk melatih siswa mempresentasikan serta bertanggung jawab atas gagasan yang telah disusun. Proses menyajikan portofolio dilaksanakan dengan cara masing-masing kelompok diminta untuk menunjuk salah seorang wakil untuk mempresentasikan portofolio dihadapan wali kelas (Bu Ttk) dan wakil kepala sekolah bidang kesiswaan (Pak Isn). Setiap kelompok diberi waktu 10 menit untuk presentasi.

\section{Refleksi Pembelajaran dan Uji Kompetensi}

Kegiatan refleksi pembelajaran dilaksanakan pada pertemuan keenam bersamaan dengan pelaksanaan Uji Kompetensi (UK). Tujuan kegiatan refleksi pembelajaran pada siklus kedua adalah memberi penguatan dan motivasi kepada siswa untuk peduli/peka terhadap lingkungan sekitar. Kegiatan pembelajaran dilanjutkan dengan Uji Kompetensi (UK). Hasil UK sebagai berikut. Ratarata nilai adalah 80,4 . Dengan rincian, rata-rata nilai butir soal yang mencerminkan keterampilan berpikir kritis adalah 83,9 dan rata-rata nilai butir soal yang mencerminkan keterampilan berpikir kreatif adalah 75,6. Berdasarkan hasil tersebut, siswa yang sudah mencapai sejumlah 28 siswa $(87,5 \%)$.

\section{Refleksi}

Refleksi pelaksanaan model pembelajaran Project Citizen untuk meningkatkan keterampilan berpikir kritis dan kreatif pada siklus kedua, adalah: (1) terdapat kesesuaian antara skenario pembelajaran yang menerapkan langkah-langkah model pembelajaran Project Citizen dengan RPP; (2) alokasi waktu yang digunakan untuk tindakan pada siklus kedua sesuai dengan RPP yaitu enam kali pertemuan; (3) perubahan skenario pembentukan kelompok hasil refleksi siklus I membuat proses pembelajaran menjadi lebih efektif untuk meningkatkan keterampilan berpikir kritis dan kreatif; (4) pendampingan dan pembimbingan guru secara intensif kepada kelompok dapat meningkatkan keterampilan berpikir kritis dan kreatif; (5) pembimbingan, nasihat, teguran secara langsung kepada siswa, efektif untuk menanamkan nilai-nilai Pancasila pada saat bermusyawarah; dan (6) pemberian hadiah bagi kelompok terbaik sangat memotivasi kelompok dalam menyelesaikan portofolio. 
Berdasarkan pengamatan yang dilakukan selama proses pembelajaran yang menerapkan model pembelajaran Project Citizen terdapat peningkatan kualitas proses langkah-langkah model pembelajaran Project Citizen sehingga dapat meningkatkan keterampilan berpikir kritis dan kreatif siswa Kelas V-D SD Islam Sabilillah Malang. Keterlaksanaan langkah-langkah model pembelajaran Project Citizen pada siklus II adalah $100 \%$. Selain itu, berdasarkan analisis Uji Kompetensi menunjukkan adanya peningkatan yaitu peningkatan rata-rata nilai UK, peningkatan nilai rata-rata soal yang mencerminkan keterampilan berpikir kritis, dan peningkatan nilai rata-rata soal yang mencerminkan keterampilan berpikir kreatif. Mengacu pada pertimbangan ketercapaian indikator keberhasilan penelitian dan keterbatasan waktu, maka penelitian tindakan kelas ini dilakukan melalui dua siklus.

\section{PEMBAHASAN}

Peran guru ketika langkah identifikasi masalah adalah diharapkan sebagai fasilitator yang mampu menyadarkan siswa bahwa banyak masalah di lingkungan sekitar (Budimansyah, 2009). Oleh sebab itu, objek kajian masalah adalah lingkungan terdekat siswa, yaitu lingkungan kelas dan sekolah. Piaget menjelaskan bahwa dalam perkembangan anak memahami sesuatu harus melalui proses adaptasi, asimilasi, dan akomodasi sehingga terjadi ekuilibrasi (Slavin, 2008). Oleh karena itu, untuk membantu siswa memahami proses identifikasi masalah, guru menggunakan media foto-foto yang menggambarkan keadaan di sekitar sekolah. Cara ini mempertegas teori perkembangan yang dijelaskan oleh Piaget bahwa anak-anak pada usia operasional kongkrit (usia 7 s.d. 11 tahun) dapat membentuk konsep, melihat hubungan, dan memecahkan masalah, tetapi hanya sejauh mereka melibatkan objek dan situasi yang sudah dikenal (Slavin, 2008). Hal tersebut selaras dengan pendapat Sumanto (2011) yang menegaskan bahwa fungsi media pembelajaran yaitu dapat digunakan untuk memperjelas penyajian pesan dan informasi serta dapat meningkatkan, mengarahkan perhatian siswa, serta membantu memudahkan pencapaian tujuan pembelajaran.

Kegiatan inti diawali dengan pembentukan kelompok. Masing-masing kelompok diminta untuk mengidentifikasi tiga masalah yang terdapat di lingkungan terdekat siswa. Pembentukan kelompok dalam proses identifikasi masalah bertujuan agar terjadi proses interaksi antar siswa sehingga pembelajaran dapat terjadi. Vygotsky menekankan bahwa perkembangan kognisi seseorang sangat terkait dengan masukan dari orang lain (Slavin, 2008). Lebih lanjut Vygotsky menyiratkan bahwa pembelajaran terjadi ketika anak bekerja dalam zona perkembangan proksimal (Slavin, 2008). Tugas-tugas dalam zona tersebut adalah sesuatu yang masih belum dapat dikerjakan anak tetapi dapat dikerjakan dengan bantuan orang lain. Dampak pengiring dari pembentukan kelompok adalah diharapkan siswa mampu membiasakan nilai-nilai Pancasila ketika melakukan musyawarah, seperti sikap menghormati pendapat orang lain, lapang dada, dan diam ketika orang lain sedang berpendapat. Terkait dengan dampak pengiring pada penerapan langkah-langkah model pembelajaran Project Citizen, guru memberi penekanan kepada kelompok untuk menggunakan cara musyawarah mufakat jika terdapat perbedaan pendapat.

Peran guru ketika proses musyawarah adalah selalu memotivasi dan mengingatkan siswa. Teguran langsung dengan cara yang halus kepada siswa yang belum bisa diam ketika orang lain sedang menyampaikan pendapat harus sering dilakukan guru. Teguran langsung ini sejalan dengan pernyataan Slavin (2008) yang menyatakan bahwa konsekuensi yang mengikuti perilaku dalam waktu yang berdekatan jauh lebih mempengaruhi perilaku daripada konsekuensi yang tertunda. Teguran langsung kepada siswa yang belum bisa diam ketika temannya menyampaikan pendapat terbukti efektif untuk menanamkan nilai-nilai. Cara ini dilakukan untuk membiasakan dan menanamkan nilai-nilai/karakter Pancasila kepada siswa. Budimansyah (2010) menjelaskan bahwa karakter itu tidak dapat dikembangkan secara cepat dan segera, tetapi harus melewati suatu proses yang panjang, cermat, dan sistemik. Perlakuan guru dalam menanamkan nilai-nilai Pancasila ketika bermusyawarah terbukti dapat meningkatkan perilaku siswa yaitu $50 \%$.

Keterampilan berpikir kritis tercermin ketika proses identifikasi masalah yaitu ketika kelompok memberikan alasan-alasan yang mendukung pada 
setiap masalah yang diidentifikasi. Setiap siswa menyampaikan alasan-alasan untuk menguatkan pendapat. Semakin banyak alasan logis yang disampaikan berarti siswa telah menerapkan keterampilan berpikir kritis. Budimansyah (2009) menyebutkan bahwa model pembelajaran Project Citizen merupakan model pembelajaran yang berorientasi pada proses berpikir kritis dan pemecahan masalah. Pernyataan Budimansyah (2009) selaras dengan Johnson (2007) yang menyatakan keterampilan berpikir kritis adalah kemampuan mengatakan sesuatu dengan penuh percaya diri. Kegiatan pembelajaran yang kurang mengembangkan kemampuan siswa untuk berpikir kreatif dan kritis belum dapat memenuhi tujuan pendidikan yang diharapkan (Gunawan, dkk., 2014).

Awalnya siswa mengalami kesulitan untuk memberikan alasan-alasan ketika mengidentifikasi masalah. Untuk itu, bimbingan guru yang intensif kepada masing-masing kelompok dengan cara memberikan contoh sebuah masalah dan alasan mengapa hal tersebut merupakan masalah. Contoh demi contoh diberikan guru untuk melatih siswa mengembangkan keterampilan berpikir kritis. Johnson (2007) menyatakan bahwa berlatih bagi pemikir kritis sama pentingnya berlatih bagi pemain tenis dan musisi. Johnson menegaskan bahwa hanya latihanlah yang membuat keterampilan itu menjadi kebiasaan. Johnson kemudian menjelaskan delapan langkah untuk menjadi pemikir kritis. Salah satunya adalah siswa dibiasakan untuk bertanya tentang apa sebenarnya masalah/isu yang sedang dibicarakan. Untuk menjawab hal tersebut, siswa harus berlatih mengetahui setepat-tepatnya masalah yang sedang dikaji. Sehingga peran guru dalam melatih siswa berpikir kritis ketika mengidentifikasi masalah adalah membantu siswa menggambarkan masalah dengan sejelas-jelasnya.

Pemberian kata-kata motivasi dan janji guru untuk memberi hadiah kepada kelompok terbaik ketika awal siklus II ternyata sangat memotivasi siswa dalam melaksanakan setiap langkah pembelajaran. Penggunaan kata-kata: hebat, good job, atau tepuk tangan merupakan motivasi yang diberikan guru pada setiap perilaku positif siswa. Hal lain yang sering diulang-ulang oleh guru adalah janji pemberian hadiah ketika siswa melaksanakan langkah-langkah model pembelajaran Project
Citizen. Cara motivasi ini sejalan dengan konsep motivasi yang dinyatakan oleh Slavin (2008) yaitu pujian-pujian motivasi dapat membantu pencapaian bagi siswa yang rendah dan membuat siswa lebih bersemangat melakukan sesuatu. Perlakukan ini membuat Siklus II menjadi lebih efisien dari segi waktu. Jika siklus I membutuhkan delapan kali pertemuan, maka siklus II berkurang menjadi enam kali pertemuan.

Langkah kedua model pembelajaran Project Citizen adalah memilih masalah. Sebagai model pembelajaran yang beroerientasi pada proses berpikir kritis dan pemecahan masalah, tentu pada proses memilih masalah tercermin aktivitas keterampilan berpikir kritis. Menurut Budimansyah (2009), pada langkah ini hendaknya kelas memusyawarahkan semua informasi yang telah di dapat berkenaan dengan daftar masalah yang ditemukan. Lebih lanjut, Budimansyah (2009) menjelaskan tujuan dari kegiatan ini adalah kelas dapat memilih satu masalah sebagai bahan kajian kelas. Dengan demikian kelas memiliki satu masalah yang merupakan pilihan bersama untuk dijadikan bahan kajian kelas. Kegiatan pemilihan masalah diawali dengan membangkitkan minat siswa untuk mengkaji dan menyelesaikan masalah. Membangkitkan minat menurut Slavin (2008) sangat penting dalam proses pembelajaran. Siswa diberikan informasi tentang pentingnya dan tingkat daya tarik bahan yang akan disajikan untuk memperlihatkan bagaimana proses pembelajaran yang akan dilakukan itu bermanfaat bagi siswa maupun orang lain.

Instructional Effects (dampak instruksional) dari KD nomor 4 yaitu Keputusan Bersama tampak pada langkah pemilihan masalah. Dampak instruksional dalam hal ini adalah pengaruh langsung dari proses belajar dan pembelajaran yang biasanya dirumuskan dalam tujuan pembelajaran (Budimansyah, 2010). Kelas dipandu untuk melakukan musyawarah mufakat guna memilih satu masalah yang akan menjadi kajian kelas. Kegiatan musyawarah kelas untuk memilih satu masalah yang akan dikaji oleh kelas. Setiap kelompok menyajikan daftar masalah yang sudah teridentifikasi beserta alasan-alasan yang mendukung. Keterampilan berpikir kritis tercermin dalam pemilihan masalah. Masing-masing kelompok dituntut untuk memberikan alasan 
yang logis dan mengambil kesimpulan. Aktivitas memberikan alasan dan mengambil kesimpulan merupakan karakteristik berpikir kritis. Menurut Murti (2012), berpikir kritis mencakup kemampuan untuk mengenali masalah, menganalisis masalah, mengambil kesimpulan dengan menggunakan bukti-bukti yang mendukung.

Johnson (2007) menegaskan bahwa tugas pemikir kritis adalah mengidentifikasi alasan dan bertanya apakah alasan-alasan yang dikemukakan masuk akal. Senada dengan pendapat sebelumnya, Harsanto (2005) menyatakan bahwa seseorang dikatakan kritis jika mampu memberikan alasan atas pilihan keputusan yang diambil. Ia harus bisa menjawab pertanyaan mengapa keputusan itu diambil. Iapun harus terbuka terhadap perbedaan keputusan dan pendapat orang lain seta sanggup menyimak alasan-alasan mengapa orang lain memiliki pendapat dan keputusan yang berbeda. Berkaitan dengan pendapat tersebut, maka ketika proses memilih masalah, tindakan guru adalah memandu, membimbing, serta mengarahkan siswa untuk mengungkapkan pendapat mengenai alasan pemilihan masalah. Guru memandu jalannya proses pemilihan masalah dan membimbing siswa untuk mengungkapkan alasan-alasan pemilihan masalah.

Pembimbingan secara intensif kepada masing-masing kelompok berimplikasi adanya peningkatan keterampilan berpikir kritis. Jika ada kelompok yang belum mampu memberikan alasan yang logis, maka guru membimbing dengan memberikan pertanyaan-pertanyaan untuk memancing kelompok memberikan alasan yang lain. Pembimbingan guru ketika Siklus II lebih intensif kepada masing-masing kelompok. Bahkan bagi kelompok yang mengalami kesulitan, guru memberikan bimbingan di luar jam pelajaran. Bimbingan intensif kepada masingmasing kelompok membuat adanya peningkatan keterampilan berpikir kritis pada saat langkah memilih masalah, yaitu 83,3\%.

Guru juga mengarahkan siswa untuk menghormati perbedaan, menghargai perbedaan alasan, serta lapang dada jika keputusan tidak digunakan. Pembiasaan untuk menerapkan nilainilai Pancasila ketika bermusyawarah menjadi perhatian guru selain keterampilan berpikir kritis dan kreatif. Teguran langsung dan nasihat yang secara terus menerus merupakan usaha guru dalam menanamkan nilai-nilai. Perlakuan guru tersebut membawa adanya peningkatan $71,9 \%$ pada perilaku siswa. Siswa menjadi lebih tertib ketika temannya menyampaikan pendapat. Namun pada siklus II, masih ada siswa yang berbicara sendiri (ramai) ketika temannya berpendapat.

Skenario guru untuk melakukan pemilihan masalah melalui pengambilan suara terbanyak, bertujuan agar siswa mengenal dan memahami cara-cara pengambilan keputusan bersama. Melalui pembelajaran konteks secara langsung diharapkan siswa mampu memahami suatu konsep tanpa harus melalui penjelasan. Siswa difasilitasi untuk memahami konsep voting, voting terbuka, maupun voting tertutup. Proses pembelajaran ini disebut pembelajaran dalam konteks. Dalam mengajarkan konsep, Slavin (2008) menjelaskan bahwa salah satu cara yang dapat digunakan untuk meningkatkan pemahaman adalah siswa menerapkan dengan tepat konsep tersebut pada situasi tertentu. Siswa belajar memahami konsep voting melalui konteks pengalaman langsung. Siswa diajak memahami konsep melalui konteks yang dilakukan siswa. Harapannya, pemahaman siswa terhadap suatu konsep lebih bermakna.

Langkah selanjutnya dalam model pembelajaranProjectCitizen adalahmengumpulkan informasi. Kelompok siswa dibagi menjadi tim-tim riset untuk mengumpulkan informasi dari berbagai sumber (Budimansyah, 2009). Tujuan langkah ini adalah agar kelas dapat memperoleh informasi tambahan yang akurat dan komprehensif guna memahami masalah yang menjadi kajian kelas. Kegiatanawal sebelum tim-tim risetmengumpulkan informasi adalah apersepsi, pemberian motivasi, dan penyampaian tujuan pembelajaran. Sebelum kelompok melakukan aktivitas mengumpulkan informasi, guru berdiskusi dengan siswa tentang sumber-sumber informasi yang dapat dikunjungi. Guru, petugas kebersihan, staf tata usaha, pegawai koperasi, maupun internet adalah contoh sumber informasi yang dapat memperkuat dan melengkapi kajian masalah. Selain itu, sebelumnya siswa dibimbing untuk menyusun pertanyaan-pertanyaan yang akan diajukan kepada narasumber untuk menghindari siswa kehabisan pertanyaan maupun bertanya di luar kajian masalah. 
Kegiatan mengumpulkan informasi memberikan banyak pengalaman belajar kepada siswa (Budimansyah, 2010). Melalui aktivitas ini siswa membiasakan untuk mengambil keputusan dengan dukungan data dan informasi yang akurat. Pengalaman belajar ini diperoleh siswa tatkala mengumpulkan data dan informasi dari berbagai sumber untuk menjawab berbagai persoalan yang menjadi bahan kajian kelas. Aktivitas mengumpulkan informasi dari berbagai sumber selaras dengan prinsip umum dari teori konstruktivisme yang menyatakan bahwa siswa memperoleh banyak pengetahuan di luar kelas. Sehingga siswa mampu membentuk dan membangun pengetahuannya melalui interaksi dengan lingkungannya (Fajar, 2002). Interaksi siswa dengan lingkungan melalui wawancara, diskusi, maupun mendengar dari orang lain dapat membentuk pengetahuan maupun mengubah pengetahuan sebelumnya.

Budimansyah (2010) bahkan menegaskan bahwa aktivitas siswa mengumpulkan informasi sebagai kemampuan yang sangat penting dimiliki oleh warga negara yang baik, sebab fatal akibatnya jika keputusan yang diambil hanya berdasarkan perasaan atau bahkan berdasarkan pertimbangan yang tidak rasional. Hal lain yang diperoleh siswa ketikamengumpulkaninformasiadalahkemampuan berkomunikasi. Bertanya, menjawab, mengulas jawaban narasumber, maupun menanggapi adalah aspek kemampuan komunikasi yang bisa diperoleh siswa. Mulyasa (2006) menyebutkan bahwa proses diskusi akan efektif jika melibatkan 3 s.d. 5 siswa. Hal ini berakibat kepada keaktifan siswa dalam menerapkan keterampilan berpikir kritis ketika melakukan pengumpulan informasi. Tidak semua siswa melakukan aktivitas bertanya kepada sumber informasi. Oleh karena itu, pada siklus II, pola pembentukan kelompok riset dirubah. Kelas dibagi menjadi enam kelompok.

Masing-masing kelompok melakukan langkah-langkah model pembelajaran Project Citizen. Siswa dalam kelompok melakukan tahap mengidentifikasi masalah, memilih masalah, mengumpulkan informasi, mengembangkan portofolio, menyajikan portofolio, serta refleksi pengalaman belajar. Peran guru sebagai fasilitator, pembimbing, serta motivator yang intensif pada saat kelompok melakukan langkah-langkah pembelajaran membawa peningkatan keterampilan berpikir kritis dan kreatif. Sebagai pembimbing, Mulyasa (2006) menjelaskan bahwa guru diibaratkan sebagai pembimbing perjalanan, yang berdasarkan pengetahuan dan pengalamannya bertanggung jawab atas kelancaran perjalanan itu. Mulyasa menyebutkan bahwa yang dimaksud perjalanan bukan hanya perjalanan fisik tetapi juga perjalanan mental, emosional, kreativitas, maupun moral. Demikian halnya dengan keterampilan berpikir kritis dan kreatif. Agar kedua keterampilan ini dimiliki oleh siswa, peran guru sebagai pembimbing perjalanan siswa selama proses pembelajaran sangatlah penting.

Mengembangkan portofolio merupakan langkah selanjutnya setelah siswa menyelesaikan proses mengumpulkan informasi selengkap mungkin terkait masalah yang dikaji. Kelas dibagi menjadi empat kelompok. Masingmasing kelompok akan bertanggung jawab untuk mengembangkan satu bagian portofolio (Budimansyah, 2009). Selanjutnya Budimansyah menjelaskan bahwa bahan-bahan yang dimasukkan dalam portofolio hendaknya dokumendokumen yang telah dikumpulkan pada langkah sebelumnya, yaitu mengumpulkan informasi. Lebih lanjut, Beliau memberi penegasan, bahwa dokumentasi harus mencakup bahan-bahan atau karya-karya yang ditulis asli oleh siswa. Kegiatan pendahuluan yang maksimal merupakan hal terpenting pada proses pengembangan portofolio. Pemberian motivasi serta arahan yang jelas terkait pengembangan portofolio menjadikan proses pengembangan portofolio berjalan efektif dan efisien. Efektif dalam arti tepat mencapai tujuan yang diharapkan, yaitu terselesaikannya portofolio lengkap dengan bagian-bagiannya serta siswa dapat mengembangkan keterampilan berpikir kritis dan kreatif. Efisien dalam arti tidak banyak waktu terbuang dalam proses pengembangan portofolio. Manfaat kegiatan pendahuluan yang maksimal membawa peningkatan $9,60 \%$ pada aspek keterampilan berpikir kritis dan $11,9 \%$ pada aspek keterampilan berpikir kreatif.

Keterampilan berpikir kritis pada langkah mengembangkan portofolio tercermin pada aktivitas siswa ketika mengembangkan hasil wawancara, mengolah data-data yang diperoleh ketika mengumpulkan informasi, dan memberikan 
alasan-alasan pemilihan masalah. Sedangkan keterampilan berpikir kreatif tercermin dari aktivitas siswa mengembangkan gagasangagasan baru untuk mengatasi masalah. Pada langkah sebelumnya, siswa mengumpulkan informasi tentang solusi yang telah dan pernah dilakukan untuk mengatasi masalah. Pada saat mengembangkan gagasan-gagasan untuk mengatasimasalah, guru melakukan pembimbingan intensif. Siswa dilatih untuk mengkaji sejauh mana solusi yang sudah dilakukan berhasil mengatasi masalah. Keterampilan berpikir kreatif pada siswa memang harus dibiasakan sejak dini. Jika pengembangan keterampilan ini dimulai sejak awal, maka akan membentuk kebiasaan berpikir siswa yang bermanfaat bagi siswa itu sendiri kelak, yaitu di mana siswa dapat mengoptimalkan dan mengaplikasikan segala potensi yang dimilikinya (Aryani, 2008).

Harsanto (2005) menyebutkan bahwa berpikir kreatif berarti mengajak Anda untuk melepaskan diri dari pola umum. Dalam proses mengembangkan gagasan-gagasan untuk mengatasi masalah, guru mendorong siswa untuk kreatif dengan cara memberikan kebebasan kepada siswa mengutarakan gagasan-gagasan baru. Johnson (2007) menjelaskan bahwa orang kreatif lahir dilengkapi dengan kekuatan untuk membayangkan kemungkinan-kemungkinan di luar yang bisa dibayangkan oleh orang biasa. Siswa didorong untuk merumuskan dan mengutarakan ide-ide baru. Mulyana (2012) menguraikan tentang ciri-ciri berpikir kreatif yang diturunkan dari fluency, flexibility, originality, dan elaboration. Ciri-ciri fluency adalah: (1) mencetuskan banyak ide, banyak jawaban, banyak penyelesaian masalah; (2) memberikan banyak cara atau saran untuk melakukan berbagai hal; dan (3) selalu memikirkan lebih dari satu jawab. Ciriciri flexibility adalah: (1) menghasilkan gagasan, jawaban yang bervariasi; dan (2) mencari banyak alternatif. Ciri-ciri originality adalah: (1) mampu melahirkan gagasan baru; dan (2) memikirkan cara yang tidak lazim. Sedangkan ciri-ciri elaboration adalah: (1) mampu memperkaya dan mengembangkan suatu gagasan; dan (2) mampu menambah detil-detil dari suatu objek, gagasan menjadi lebih menarik. Ciri-ciri berpikir kreatif ditegaskan lebih lanjut oleh Suharnan (2011) yang mengatakan bahwa di dalam konteks pemecahan masalah, berpikir kreatif merupakan kemampuan untuk menghasilkan gagasan-gagasan baru yang menarik dan bernilai bagi suatu pemecahan masalah. Selain itu, Suharnan menjelaskan bahwa berpikir kreatif merupakan kemampuan seseorang untuk mencari berbagai alternatif baik dalam bentuk pemikiran, pendekatan masalah, ataupun aktivitas.

Berdasarkan hasil observasi tindakan, pengembangan portofolio lebih efektif dikerjakan oleh kelompok kecil (3 s.d. 5 siswa) dibandingkan kelompok besar (10 s.d. 15 siswa). Pengembangan portofolio yang dilakukan kelompok kecil membawa implikasi semua siswa dalam kelompok aktif dalam penyelesaian portofolio. Semua siswa mengetahui secara rinci permasalahan, data-data, dan informasi tentang masalah, dan memahami gagasan-gagasan yang dikembangkan kelompok. Sedangkan siswa dalam kelompok besar cenderung banyak yang pasif. Hanya sebagian siswa saja yang mengembangkan portofolio. Hal tersebut membawa implikasi kepada kurangnya pemahaman siswa terhadap masalah yang dikaji dan gagasan untuk mengatasi masalah. Jika portofolio sudah selesai, para siswa dapat menyajikan hasil pekerjaannya dihadapan para hadirin. Presentasi portofolio atau yang disebut showcase dapat dilakukan dihadapan 2 s.d. 4 dewan juri. Melalui kegiatan ini, siswa dibekali dengan pengalaman belajar tentang cara mempresentasikan ide-ide dan pemikiran kepada orang lain (Budimansyah, 2009). Selanjutnya Budimansyah menjelaskan tujuan dari kegiatan menyajikan portofolio (showcase) adalah: (1) memberikan informasi kepada para hadirin tentang pentingnya masalah yang dikaji; (2) menjelaskan dan memberikan penilaian atas kebijakan alternatif; (3) mendiskusikan dengan para hadirin bahwa kebijakan yang dipilih adalah kebijakan yang paling baik untuk menangani permasalahan tersebut; dan (4) menunjukkan bagaimana cara mendapatkan dukungan dari pihak lain.

Setelah proses penyajian portofolio, dilakukan proses tanya jawab dengan pihak sekolah (dewan juri). Ketika proses tanya jawab, Budimansyah (2009) menjelaskan kemungkinan yang akan ditanyakan dewan juri, yaitu: (1) menjelaskan lebih jauh tentang permasalahan; (2) memberikan contoh-contoh yang jelas tentang permasalahan; 
(3) mempertahankan gagasan; dan (4) pertanyaan lain tentang pengalaman selama penyelesaian portofolio. Berdasarkan hal tersebut, pertanyaan yang diajukan pihak sekolah (dewan juri) lebih banyak tentang penegasan tentang permasalahan dan alternatif lain jika gagasan yang disampaikan kelompok tidak berhasil. Keterampilan berpikir kritis dan kreatif tercermin dari aktivitas tanya jawab antara kelompok dengan pihak sekolah (dewan juri). Kelompok diharuskan menjelaskan lebih detail tentang permasalahan yang dikaji sekaligus dengan memberikan alasan-alasan yang mendukung. Kelompok dituntut kritis untuk menanggapi pertanyaan yang diajukan dewan juri terkait permasalahan maupun gagasan yang disampaikan kelompok. Bahkan ketika tanya jawab, kelompok dituntut untuk mempertahankan gagasannya. Keterampilan berpikir kreatif tercermin dari aktivitas kelompok ketika menyampaikan gagasan baru untuk mengatasi masalah. Dimungkinkan dewan juri bertanya tentang apa yang dilakukan jika gagasan kelompok tidak/belum berhasil mengatasi masalah.

Langkah terakhir dari model pembelajaran Project Citizen adalah merefleksikan pengalaman belajar. Kegiatan ini merupakan salah satu cara untuk belajar, untuk menghindari agar jangan sampai melakukan kesalahan yang sama, dan untuk meningkatkan kemampuan yang sudah dimiliki siswa (Budimansyah, 2009). Pada langkah ini, lebih lanjut Budimansyah (2009) menjelaskan bahwa hendaknya refleksi pengalaman belajar menggambarkan secara singkat tentang: apa yang telah dipelajari siswa/kelas dan bagaimana caranya; dan cara apa yang akan siswa gunakan jika mereka nantinya akan mengembangkan portofolio yang lain (Budimansyah, 2010).

Berdasarkan hal tersebut, kegiatan refleksi pengalaman belajar dilakukan setelah semua kelompok selesai menyajikan portofolio. Guru memandu kegiatan refleksi pembelajaran dengan cara memberi pertanyaan kepada siswa tentang halhal apa yang sudah dilakukan siswa, informasi apa yang diperoleh siswa ketika proses mengumpulkan informasi, dan hambatan yang dialami ketika mengembangkan portofolio. Selain itu, guru memberi motivasi agar siswa selalu berpikir kritis dan kreatif. Siswa diharapkan memiliki sikap peduli dan kritis terhadap masalah-masalah yang ada. Guru juga memberi penekanan kepada siswa untuk peduli, kritis, dan kreatif. Keterampilan berpikir kritis dan kreatif diharapkan jangan berhenti pada pelajaran PKn saja. Siswa diberi penekanan untuk peduli, kritis, dan kreatif pada lingkungan sekitar. Kegiatan refleksi pengalaman belajar diakhiri dengan pemilihan kelompok terbaik dan pemberian hadiah.

\section{SIMPULAN DAN SARAN}

\section{Simpulan}

Setelah melalui tindakan Siklus I dan II, maka kesimpulan dari penelitian ini adalah: (1) setelah pelaksanaan pembelajaran $\mathrm{PKn}$ pada materi pokok keputusan bersama dapat disimpulkan bahwa penerapan model pembelajaran Project Citizen dengan kelompok kecil (4 s.d. 6 siswa), melalui kegiatan pendahuluan yang optimal, adanya pembimbingan guru yang intensif, serta adanya motivasi ektrinsik berupa hadiah dapat meningkatkan keterampilan berpikir kritis dan kreatif pada siswa Kelas V-D SD Islam Sabilillah Malang; (2) melalui langkah-langkah model pembelajaran Project Citizen tersebut, dapat meningkatkan keterampilan berpikir kritis siswa. Hal tersebut terlihat dengan adanya peningkatan nilai rata-rata butir soal yang mencerminkan keterampilan berpikir kritis yaitu 9,60; dan (3) langkah-langkah model pembelajaran project citizen yang terdiri dari 6 (enam) langkah, juga dapat meningkatkan keterampilan berpikir kreatif. Hal tersebut terlihat dengan adanya peningkatan ratarata butir soal yang mencerminkan keterampilan berpikir kreatif yaitu 4,80 .

\section{Saran}

Berdasarkan hasil penelitian yang telah diuraikan di atas, saran yang disampaikan bagi guru PKn adalah jika waktu pembelajaran tidak mencukupi, guru sebaiknya menggunakan waktu di luar jam pembelajaran untuk membimbing siswa untuk meningkatkan keterampilan berpikir kritis dan kreatif. Bagi Lembaga Pendidikan Sekolah Dasar adalah merancang unit organisasi sekolah yang fokus pada cara meningkatkan keterampilan berpikir kreatifdan kritis siswa. Kepada peneliti lain adalah memanfaatkan hasil penelitian ini sebagai bahan rujukan untuk merancang penelitian baru 
atau penelitian sejenis dengan menerapkan model pembelajaran Project Citizen untuk meningkatkan keterampilan berpikir kritis dan kreatif.

\section{DAFTAR RUJUKAN}

Akbar, S. 2009. Model-model Pembelajaran Terpadu Pendidikan Kewarganegaraan SD: Pengembangan Nilai dan Karakter Berorientasi Teori Komprehensif. Malang: UM Press.

Amri, S. 2010. Proses Pembelajaran Kreatif dan Inovatif dalam Kelas: Metode, Landasan Teori Praktis dan Penerapannya. Jakarta: Prestasi Pustaka.

Aryani, F. 2008. Kreativitas dalam Pembelajaran. Didaktika Jurnal Ilmu Kependidikan, 3(2), 1-10.

Baisa, I. R. 2010. Pengaruh Pembelajaran Model Web terhadap Keterampilan Berpikir Kritis dan Kemampuan Kognitif Siswa Kelas V SD Islam Sabilillah Malang. Tesis tidak diterbitkan. Malang: PPs UM.

Budimansyah, D. 2009. Inovasi Pembelajaran Project Citizen. Bandung: Program Studi Pendidikan Kewarganegaraan SPs UPI.

Fajar, A. 2002. Portofolio dalam Pelajaran IPS. Bandung: PT Remaja Rosdakarya.

Gunawan, I., Suraya, S. N., dan Tryanasari, D. 2014. Hubungan Kemampuan Berpikir Kreatif dan Kritis dengan Prestasi Belajar Mahasiswa pada Matakuliah Konsep Sains II. Premiere Educandum, 4(1), 1-32.

Harsanto, R. 2005. Melatih Anak Berpikir Analitis, Kritis, dan Kreatif. Jakarta: PT Gramedia Widiasarana Indonesia.

Hodijah, E. 2010. Pengaruh Pembelajaran Model Project Citizen terhadap Pengembangan Kompetensi Kewarganegaraan Siswa SMA dalam Materi Pemahaman Persamaan Gender. Tesis tidak diterbitkan. Bandung: SPs UPI.
Jayadiputra, E. 2010. Pengaruh Implementasi Model Project Citizen dalam Pendidikan Kewarganegaraan terhadap Keterampilan Berpikir Kritis Siswa pada Konsep Demokrasi. Tesis tidak diterbitkan. Bandung: SPs UPI.

Johnson, E. B. 2002. Contextual Teaching and Learning: Menjadikan Kegiatan BelajarMengajar Mengasyikkan dan Bermakna. Terjemahan oleh Ibnu Setiawan. Bandung: Mizan Learning Center (MLC).

Kemmis, S., dan Taggart, R. M. 1990. The Action Research Planner. Victoria: Deakin University.

Mulyana, T. 2012. Kemampuan Berpikir Kritis dan Kreatif. Bandung: UPI.

Mulyasa. 2006. Menjadi Guru Profesional: Menciptakan Pembelajaran Kreatif dan Menyenangkan. Bandung: PT Remaja Rosda Karya.

Murti, B. 2012. Berpikir Kritis (Critical Thinking) - Seri Kuliah Blok Budaya Ilmiah, (Online), (www.fk.uns.ac.id/static/file/criticalthinking. pdf), diakses 9 Juni 2012.

Rofi'uddin, A. 2000. Model Pendidikan Berpikir Kritis-Kreatif untuk Siswa Sekolah Dasar. Jurnal Bahasa dan Seni. Jurnal Bahasa, Sastra, Seni, dan Pengajarannya, 28(1), 7294.

Slavin, R. E. 2008. Educational Psycology: Theory and Practice. Terjemahan oleh Marianto Samosir. Jakarta: PT Indeks.

Suharnan. 2011. Kreativitas: Teori dan Pengembangan. Surabaya: Penerbit Laras.

Sumanto. 2011. Modul Pengembangan Media Pembelajaran SD. Malang: Panitia Sertifikasi Guru (PSG) Rayon 15, Universitas Negeri Malang, Kementerian Pendidikan Nasional. 